\title{
ANALYSIS OF HEMATOLOGICAL VARIABLES AMONG COMPETI- TORS IN VARIOUS GAMES
}

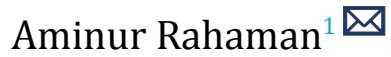 \\ ${ }^{1}$ Department of Physical Education and Sport Science, Visva-Bharati University, Santiniketan, West Bengal, India
}
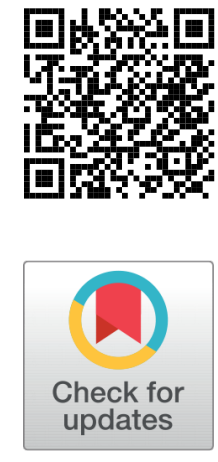

\section{ABSTRACT}

Received 6 May 2021

Accepted 20 May 2021

Published 31 May 2021

Corresponding Author

Aminur Rahaman, aminur.rahama

n844@gmail.com

DOI $10.29121 /$

granthaalayah.v9.i5.2021.3969

Funding: This research received no specific grant from any funding agency in the public, commercial, or not-for-profit sectors.

Copyright: (C) 2021 The Author(s). This is an open access article distributed under the terms of the Creative Commons Attribution License, which permits unrestricted use, distribution, and reproduction in any medium, provided the original author and source are credited.

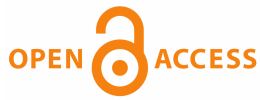

Hematological factors may be useful in determining the best physical performance of various game participants. It also indicates the athletes' health and physical condition. This study deals with the analysis of hematological variables-red blood cells, white blood cells (neutrophil, eosinophil, lymphocytes, monocytes), and platelet among university men basketball, volleyball, and cricket players. Fourteen (14) active players (basketball-5, volleyball-5, and cricket-4) were taken as samples and age range between 20 to 25 years. All players were actively competing at Inter-University levels in their respected sport and they voluntarily participated in this study. Blood samples were collected in the morning session with fasting. Red blood cells, white blood cells, platelet counts were criterion measures in this study. The obtained data were analyzed by one-way ANOVA with the help of SPSS software and the level of significance was set at $\mathrm{p}<0.05$. As per the statistical analysis, insignificant differences were found among the three different game players. In summary, the study found that the red blood cells, white blood cells, and platelet counts are similar in the three groups.

Keywords: Hematology, Blood, Red Blood Cells, White Blood Cells, Platelets, Games, Players

\section{INTRODUCTION}

Physical activity through regular exercise has been shown to improve physical, physiological, and other health effects. There is scientific evidence that the acute and chronic effects of regular exercise on several physiological systems have favorable effects Koç et al. (2018). Using auditory and visual information, this majority regular exercise is completed Rahman and Islam (2021) . Whereas, additionally, regular exercise helps to enhance body awareness while also reducing the risk of joint sprains, muscular strains, joint pain, muscular pain, and tension Rahman and Islam (2020). On the other hand, the function of physiological systems such as the cardiovascular, immunological, and endocrine systems are all evaluated using blood as an 
indication Kenney et al. (2015). Regular physical activity and exercise are thought to be significant regulators of blood cells and their activities Ludlow et al. (2013), Büttner et al. (2007). Different findings have been reported concerning hematologic parameters in the peripheral blood during and after exercise and physical activity Pedersen (2000). As a result, there is a close link between regular exercise and hematology.

Plasma, red blood cells (RBC), white blood cells (WBC), and platelets are the most common components of blood Ghosh and Das (2013) and in sports physiology, it's especially essential because it transports oxygen, carbon dioxide, and other nutrients that tissues require AHMADIZAD and EL-SAYED (2003), Akar et al. (1992), Arslan et al. (1992). Hematology studies look at the blood, blood proteins, and bloodproducing organs. The study of blood, especially how blood impacts general health and illness, is known as hematology. Infection, anemia, inflammation, hemophilia, blood-clotting problems, leukemia, and the body's response to chemotherapy regimens are all conditions that these tests can assess Gonzaba (2018).

Depending on the length of the competition and the intensity of the physical performance, hematological parameters may be impacted Alwaid (2021). Type, intensity, exercise duration, eating condition, and supplements can all affect hematological and biochemical parameters Çinar et al. (2016). The biochemical and hematological variables are significantly altered by varied environmental match practices Sureshkumar et al. (2011). Humans undergo a variety of hematological alterations as a result of both acute and chronic exercise Wardyn et al. (2008). Physical activity causes changes in the number of leucocytes and their subgroups in the circulating blood, according to researchers Robson et al. (1999). Due to hemoconcentration and platelet release from the liver, lungs, and, most crucially, the spleen, acute exercise induces a temporary rise in platelet count Chamberlain et al. (1990), Schmidt and Rasmussen (1984), Bakovic et al. (2013).

The analysis of hematology has proven that the impact of everyday exercise on hematology is different. It is said that those variations rely upon the severity, length, and frequency of exercising in addition to the bodily and physiological situations of subjects. Furthermore, the severity, length, and frequency of exercising must are well prepared to have a comparable wonderful effect on blood biochemistry Baltaci et al. (1998). In view of the fact that everyday exercise boosts the immune and metabolic systems Islam et al. (2020)and these sports activity may impact the blood count. Therefore, to the best of the authors' knowledge, there are just a few pieces of research on hematological variables in basketball, volleyball, and cricket players. With this in mind, the researcher decided to compare hematological variables among basketball, volleyball, and cricket players in the current study. 


\section{METHODOLOGY}

Fourteen (14) university-level male players (five basketball players, five volleyball players, and four cricket players) were selected randomly from Visva-Bharati University, Santiniketan, West Bengal, India. Their age ranged from 20 to 25 years. All players participated in the university-level competition.

Table 1 The characteristics of the players (Mean \pm SD)

\begin{tabular}{cccc}
\hline Items & $\begin{array}{c}\text { Basketball } \\
\text { Players }(\mathbf{n = 0 5})\end{array}$ & $\begin{array}{c}\text { Volleyball Players } \\
(\mathbf{n = 0 5})\end{array}$ & $\begin{array}{c}\text { Cricket Players } \\
\mathbf{( n = 0 4 )}\end{array}$ \\
Age (yr) & $22.80 \pm 2.17$ & $22.40 \pm 0.55$ & $22.75 \pm 2.22$ \\
Weight (kg) & $66.60 \pm 4.67$ & $64.00 \pm 2.74$ & $67.25 \pm 7.09$ \\
Height (m) & $1.71 \pm 0.08$ & $1.68 \pm 0.01$ & $1.69 \pm 0.07$ \\
BMI (kg/m $\left.\mathbf{m}^{2}\right)$ & $22.72 \pm 0.79$ & $22.70 \pm 1.02$ & $23.50 \pm 0.81$ \\
\hline
\end{tabular}

In this study researcher wanted to measures six hematological parameters of the selected players.

\begin{tabular}{|cc|}
\hline Table 2 Hematological parameters \\
\hline Blood Parameters & Methods \\
Red blood cell & In counts (million/c.mm) \\
Neutrophil & In counts /c.mm \\
Eosinophil & In counts /c.mm \\
Lymphocytes & In counts /c.mm \\
Monocytes & In counts /c.mm \\
Platelet & In counts (Lakhs/c.mm) \\
\hline
\end{tabular}

Blood samples were obtained in the indicated sterile container during the morning session with fasting. Blood samples were collected by trained medical technicians and forwarded to the pathological laboratory for analysis using precise scientific laboratory procedures. The results were compiled in a printed format with letterhead and seal. The data were analyzed using descriptive statistics; mean, standard deviation (SD), standard error of mean (SEM), minimum and maximum scores. One-way analysis of variance (ANOVA) was calculated by the SPSS software.

\section{RESULTS}

Table 3 Descriptive statistics of three different games players on hematological variables

\begin{tabular}{llllllll} 
Variables & Players & N & Mean & SD & SE & Minimum & Maximum \\
Red blood cell & Basketball & 5 & 4.70 & 0.34 & 0.15 & 4.40 & 5.20 \\
& Volleyball & 5 & 4.86 & 0.26 & 0.12 & 4.50 & 5.10 \\
\hline & & & & & & \multicolumn{3}{c}{ Continued on next page }
\end{tabular}




\begin{tabular}{llllllll}
\hline Table 3 continued & & & & & & \\
\hline & Cricket & 4 & 4.60 & 0.36 & 0.18 & 4.10 & 4.90 \\
Neutrophil & Basketball & 5 & 5343.40 & 418.90 & 187.34 & 4992.00 & 5904.00 \\
& Volleyball & 5 & 4983.20 & 708.78 & 316.97 & 4071.00 & 5670.00 \\
& Cricket & 4 & 5307.00 & 368.42 & 184.21 & 4950.00 & 5670.00 \\
\hline \multirow{2}{*}{ Eosinophil } & Basketball & 5 & 206.00 & 44.18 & 19.76 & 154.00 & 246.00 \\
& Volleyball & 5 & 197.40 & 33.50 & 14.98 & 162.00 & 231.00 \\
& Cricket & 4 & 213.75 & 36.11 & 18.06 & 162.00 & 246.00 \\
\hline \multirow{2}{*}{ Monmphocytes } & Basketball & 5 & 2291.40 & 223.36 & 99.89 & 1968.00 & 2496.00 \\
& Volleyball & 5 & 2402.80 & 225.98 & 101.06 & 2187.00 & 2700.00 \\
& Cricket & 4 & 2201.25 & 97.06 & 48.53 & 2072.00 & 2296.00 \\
& Basketball & 5 & 79.20 & 2.17 & 0.97 & 77.00 & 82.00 \\
\hline \multirow{2}{*}{ Platelet } & Volleyball & 5 & 76.60 & 4.98 & 2.23 & 69.00 & 81.00 \\
& Cricket & 4 & 78.00 & 4.08 & 2.04 & 74.00 & 82.00 \\
\hline & Basketball & 5 & 3.70 & 0.29 & 0.13 & 3.30 & 4.10 \\
\hline & Volleyball & 5 & 3.32 & 0.30 & 0.14 & 3.10 & 3.70 \\
\hline
\end{tabular}

Table 3 shows that hematological parameters of basketball, volleyball and cricket players mean and SD of RBC $4.70 \pm 0.34,4.86 \pm 0.26,4.60 \pm 0.36$; Neutrophil $5343.40 \pm 418.90$, 4983.20 $\pm 708.78,5307.00 \pm 368.42$; Eosinophil 206.00 \pm 44.18 , $197.40 \pm 33.50,213.75 \pm 36.11$; Lymphocytes $2291.40 \pm 223.36,2402.80 \pm 225.98$, 2201.25 $\pm 97.06 ; \quad$ Monocytes 79.20 $\pm 2.17, \quad 76.60 \pm 4.98,78.00 \pm 4.08 ; \quad$ Platelet $3.70 \pm 0.29,3.32 \pm 0.30,3.35 \pm 0.21$ respectively.

\begin{tabular}{|c|c|c|c|c|c|c|}
\hline Variables & Variation & $\begin{array}{l}\text { Sum of } \\
\text { Squares }\end{array}$ & df & $\begin{array}{c}\text { Mean } \\
\text { Square }\end{array}$ & $\begin{array}{c}\text { F- } \\
\text { value }\end{array}$ & $\begin{array}{c}\text { p- } \\
\text { value }\end{array}$ \\
\hline \multirow[t]{2}{*}{$\begin{array}{l}\text { Red blood } \\
\text { cell }\end{array}$} & $\begin{array}{l}\text { Between } \\
\text { Groups }\end{array}$ & 0.16 & 2 & 0.08 & 0.77 & 0.485 \\
\hline & Within Groups & 1.11 & 11 & 0.10 & & \\
\hline \multirow[t]{2}{*}{ Neutrophil } & $\begin{array}{l}\text { Between } \\
\text { Groups }\end{array}$ & 383359.21 & 2 & 191679.61 & 0.68 & 0.529 \\
\hline & Within Groups & 3118566.00 & 11 & 283506.00 & & \\
\hline \multirow[t]{2}{*}{ Eosinophil } & $\begin{array}{l}\text { Between } \\
\text { Groups }\end{array}$ & 599.76 & 2 & 299.88 & 0.20 & 0.819 \\
\hline & Within Groups & 16209.95 & 11 & 1473.63 & & \\
\hline \multirow[t]{2}{*}{ Lymphocytes } & $\begin{array}{l}\text { Between } \\
\text { Groups }\end{array}$ & 91802.68 & 2 & 45901.34 & 1.17 & 0.347 \\
\hline & Within Groups & 432094.75 & 11 & 39281.34 & & \\
\hline \multirow[t]{2}{*}{ Monocytes } & $\begin{array}{c}\text { Between } \\
\text { Groups }\end{array}$ & 16.93 & 2 & 8.46 & 0.55 & 0.590 \\
\hline & Within Groups & 168.00 & 11 & 15.27 & & \\
\hline \multirow[t]{2}{*}{ Platelet } & $\begin{array}{l}\text { Between } \\
\text { Groups }\end{array}$ & 0.43 & 2 & 0.22 & 2.85 & 0.101 \\
\hline & Within Groups & 0.84 & 11 & 0.08 & & \\
\hline
\end{tabular}

*Significant at 0.05 level; F $0.05(2,11)=3.982$ 
Table 4 provides hematological parameters data on the relation between red blood cell, neutrophil, eosinophil, lymphocyte, monocyte, and platelet of basketball, volleyball and cricket players. The red blood cell comparison is $\mathrm{p}=0.485(\mathrm{~F}=0.77)$, neutrophil $p=0.529(F=0.68)$, eosinophil $p=0.819(F=0.20)$, lymphocytes $p=0.347$ $(\mathrm{F}=1.17)$, monocytes $\mathrm{p}=0.590(\mathrm{~F}=0.55)$, and platelet $\mathrm{p}=0.101(\mathrm{~F}=2.85)$. As the obtained F-value were lower than the table F-value. So no significantly differences were found among the three different games players ( $p>0.05)$.

\section{DISCUSSIONS}

The purpose of the study was to compare hematological parameters in various sports disciplines. This study will provide about some hematological parameters and also understand that the how much different each of others games players. According to Parmar (2013) suggested that the rate of red blood cells in football players is higher than the basketball and volleyball players. Endurance sports activities for a longer length of time diminish hemoglobin and red blood cell count in athletes, which increases their athletic performance as compared to non-athletes Sujatha and Andrew (2016). Performing combination training is beneficial to physiological and hematological changes as well as the performance of elite basketball players Talaee et al. (2017). The blood counts of monocytes and platelets were greater in basketball players than in yoga practitioners, while the blood counts of red blood cells, neutrophils, eosinophils, basophils, and lymphocytes were similar between groups Rahaman (2021) . The decrease of blood parameters in a certain sport exhibits a similar pattern in both sexes, and the specific variations in red blood cell variables are also connected to the kind of activity, such as soccer, swimming, rowing, wrestling, athletics, and so on Schobersberger et al. (1990). The red blood cell count was reduced as a result of the high-intensity endurance training Bandyopadhyay et al. (2008).

\section{CONCLUSIONS}

Finally, results show that no significant differences were found among the three different game players. The present study concluded that red blood cells, neutrophil, eosinophil, lymphocyte, monocyte, and platelet blood counts are similar in basketball, volleyball, and cricket players.

\section{LIMITATION}

In this study, the sample sizes were too small. 


\section{ACKNOWLEDGEMENT}

The author gratefully acknowledges the help of the entire participant who took part in the study.

\section{CONFLICTS OF INTEREST}

The author declares that there is no conflict of interest regarding the publication of this paper.

\section{REFERENCES}

AHMADIZAD, S., \& EL-SAYED, M. S. (2003). The Effects of Graded Resistance Exercise on Platelet Aggregation and Activation. Medicine \& Science in Sports \& Exercise, 35(6), 1026-1032. Retrieved from https://dx.doi.org/10.1249/01.mss.0000069406.54766 .c6 10.1249/01.mss.0000069406.54766.c6

Akar, S., Beydagı, H., Temoçin, S., Süer, C., \& Erenmemişoglu, A. (1992). Effect Of Exercise On Some Hematologic Parameters. Turkish J. Sport Med, 27(3), 93-98.

Alwaid, S. H. (2021). The Effects Of Different Intensive Physical Performances By Athletes On Selected Hematological Parameters. Indian Journal of Forensic Medicine \& Toxicology, 15(1), 2199-2203.

Arslan, C., Gonul, B., Kaplan, B., \& Dinçer, S. (1992). Comparison Of Some Respiration And Blood Parameters Between Elite Women Athletes And Sedentary Individuals. Turk. J. Sport Med, 27(4), 113-118.

Bakovic, D., Pivac, N., Eterovic, D., Breskovic, T., Zubin, P., Obad, A., \& Dujic, Z. (2013). The effects of low-dose epinephrine infusion on spleen size, central and hepatic circulation and circulating platelets. Clinical Physiology and Functional Imaging, 33(1), 3037. Retrieved from https://dx.doi.org/10.1111/j.1475-097x.2012.01156.x 10.1111/ j.1475-097x.2012.01156.x

Baltaci, A. K., Mogulkoc, R., Ustundag, B., Koç, S., \& Ozmerdivenli, R. (1998). A Study On Some Hematological Parameters And The Levels Of Plasma Proteins And Serum Zinc, Calcium And Phosphorus In Young Female Athletes. Journal of Physical Education And Sport, $3(2), 21-28$.

Bandyopadhyay, A., Chatterjee, S., \& Chatterjee, P. (2008). Red Blood Cell Variables In Volleyball Players Of Kolkata. India. Journal Of Exercise Science And Physiotherapy, 4(1), 24-29.

Büttner, P., Mosig, S., Lechtermann, A., Funke, H., \& Mooren, F. C. (2007). Exercise affects the gene expression profiles of human white blood cells. Journal of Applied Physiology, 102(1), 26-36. Retrieved from https://dx.doi.org/10.1152/japplphysiol.00066.2006 10.1152/japplphysiol.00066.2006

Chamberlain, K. G., Tong, M., \& Penington, D. G. (1990). Properties of the exchangeable splenic platelets released into the circulation during exercise-induced thrombocytosis. American Journal of Hematology, 34(3), 161-168. Retrieved from https://dx.doi.org/ 10.1002/ajh.2830340302 10.1002/ajh.2830340302

Çınar, V., Akbulut, T., Öner, S., Pancar, Z., \& Karaman, M. E. (2016). An Investigation Of Healthylife Style Behaviors Of Turkish Wrestling Federation Coaches. International Refereed Academic Journal of Sports, Health And Medical Sciences, 21, 119-136. 
Ghosh, A., \& Das, S. S. (2013). Immediate Effect of Aerobic Exercise on Hematological Parameters. International Journal of Physical Education, Fitness and Sports, 2(2), 34-39. Retrieved from https://dx.doi.org/10.26524/1325 10.26524/1325

Gonzaba. (2018). What Are Common Hematology Tests? What Are Common Hematology Tests? / Gonzaba Medical Group. Retrieved from Https://Gonzaba.Com/What-Are -Common-Hematology-Tests/

Islam, M. S., Rahman, M. H., \& De, A. (2020). Exercising With Face Mask During The Pandemic: A Qualitative Analysis. Saudi Journal Of Sports Medicine, 20(3), 59-63.

Kenney, W. L., Wilmore, J. H., \& Costill, D. L. (2015). Physiology Of Sport And Exercise. Physiology Of Sport And Exercise.

Koç, H., Özen, G., Abanoz, H., \& Pulur, A. (2018). Comparative analysis of hematological parameters in well-trained athletes and untrained men. Pedagogics, psychology, medicalbiological problems of physical training and sports, 22(5), 260-260. Retrieved from https://dx.doi.org/10.15561/18189172.2018.0506 10.15561/18189172.2018.0506

Ludlow, A. T., Ludlow, L. W., \& Roth, S. M. (2013). Do Telomeres Adapt to Physiological Stress? Exploring the Effect of Exercise on Telomere Length and Telomere-Related Proteins. BioMed Research International, 2013(5), 1-15. Retrieved from https://dx.doi.org/10 .1155/2013/601368 10.1155/2013/601368

Parmar, D. (2013). Comparative Analysis Of Selected Hematological Variables Among University Men Basketball Football And Volleyball Players. Indian Journal of Applied Research, 3(3), 320-321.

Pedersen, B. K. (2000). Effects of exercise on lymphocytes and cytokines. British Journal of Sports Medicine, 34(4), 246-251. Retrieved from https://dx.doi.org/10.1136/bjsm.34 .4 .246 10.1136/bjsm.34.4.246

Rahaman, A. (2021). A Comparative Study Of Hematological Variables Between Basketball Players And Yoga Practitioners. Journal Of Advances In Sports And Physical Education, 4(5), 90-94.

Rahman, M. H., \& Islam, M. S. (2020). Stretching And Flexibility: A Range Of Motion For Games And Sports. European Journal Of Physical Education And Sport Science, 6(8), 22-36.

Rahman, M. H., \& Islam, M. S. (2021). Investigation Of Audio-Visual Simple Reaction Time Of University Athletes And Non-Athletes. Journal Of Advances In Sports And Physical Education, 4(3), 24-29.

Robson, P. J., Blannin, A. K., Walsh, N. P., Castell, L. M., \& Gleeson, M. (1999). Effects Of Exercise Intensity, Duration And Recovery On In Vitro Neutrophil Function In Male Athletes. International Journal of Sports Medicine, 20(2), 128-135.

Schmidt, K. G., \& Rasmussen, J. W. (1984). Exercise-Induced Changes In The In Vivo Distribution Of 111In-Labelled Platelets. Scandinavian Journal Of Haematology, 32(2), 159166.

Schobersberger, W., Tschann, M., Hasibeder, W., Steidl, M., Herold, M., Nachbauer, W., \& Koller, A. (1990). Consequences of 6 weeks of strength training on red cell 02 transport and iron status. European Journal of Applied Physiology and Occupational Physiology, 60(3), 163-168. Retrieved from https://dx.doi.org/10.1007/bf00839152 10.1007/ bf00839152

Sujatha, B., \& Andrew, S. (2016). A Comparative Study of Selective Haematological Parameters of Female Sports and Non Sports Persons. International Journal of Current Research and Academic Review, 4(4), 174-179. Retrieved from https://dx.doi.org/10.20546/ijcrar .2016.404.021 10.20546/ijcrar.2016.404.021

Sureshkumar, D., Sekarbabu, K., Ravindran, G., Krishnaswamy, S., \& Balakrishnan, A. (2011). 
Effect Of Different Environment Volleyball Practice On Selected Biochemical And Hematological Variables. Recent Research In Science And Technology, 3(1), 101-104.

Talaee, M., Nazem, F., Taherabadi, S. J., \& Sajadi, S. (2017). Effects Of Six Weeks Combined Training Program On Hematological Parameters In Elite Basketball Players. Annals of Applied Sport Science, 5(1), 15-23.

Wardyn, G. G., Rennard, S. I., Brusnahan, S. K., McGuire, T. R., Carlson, M. L., Smith, L. M., McGranaghan, S., \& Sharp, J. G. (2008). Effects of exercise on hematological parameters, circulating side population cells, and cytokines. Experimental Hematology, 36(2), 216223. Retrieved from https://dx.doi.org/10.1016/j.exphem.2007.10.003 10.1016/j .exphem.2007.10.003 